\title{
ГИДРОГЕЛЕВЫЕ ПЛЕНКИ \\ С ЛЕКАРСТВЕННЫМИ ПРЕПАРАТАМИ
}

\section{Т.Г.Тюрина, Т.И. Завязкина}

ГУ «Институт физико-органической химии и углехимии им. Л.М. Литвиненко», 283114, Украина, г. Донецк, ул. Р. Люксембург, 70.

DOI: 10.19163/MedChemRussia2021-2021-480

E-mail:t_tiurina@mail.ru

Гидрогелевые материалы на основе биосовместимых полимеров широко применяются в качестве материалов биомедицинского назначения (полимерные матрицы-платформы для доставки лекарственных препаратов, раневые антибактериальные повязки и др.) [1, 2]. Наряду с распространенным применением поли(винилового спирта) (ПВС) в качестве полимерной матрицы [2-4], перспективным представляется также использование сополимеров малеинового ангидрида (МА), в частности, с винилацетатом (BA) $[5,6]$.

Целью данной работы было получение карбоксил-содержащего гидрогеля, наполненного лекарственным веществом (ЛВ), и изучение высвобождения ЛВ из геля.

С использованием ПВС и сополимера МА-ВА (4:1) получены пленки, наполненные ЛВ (фурацилин или новокаина гидрохлорид), и определены их основные характеристики: степень набухания 320-220\%, доля геля 90-97\%, содержание ЛВ от 0,1 до 1,5\% в сухой пленке. Установлено, что основным фактором, влияющим на характеристики пленок, является концентрация инициатора (персульфат аммония), а также режим отверждения.

Высвобождение ЛВ из гидрогеля в дистиллированную воду или физраствор изучено методом электронной спектроскопии. Найдено, что высвобождение фурацилина протекает с высокой скоростью: 55-65\% ЛВ, содержащегося в пленке, выделяется в раствор в течение 10 мин. Напротив, выделение новокаина в раствор протекает существенно медленнее, что может быть связано с возможностью ковалентного связывания аминогруппы ЛВ со звеном МА в процессе сушки.

\section{Литература}

[1] M. Teodorescu, M. Bercea, and S. Morariu, Biotechnology Advances. 2019, 37, 109-131.

[2] M.V. Grigorieva, Biotechnology. 2011, 4(2), 9-23.

[3] A.A. Artyukhov, M.I. Shtilman, A.N. Kuskov, L.I. Pashkova, A.M. Tsatsakis and A.K. Rizos, Journal of non-ciystalline solids. 2010, 357, $700-706$.

[4] D. Darwis, P. Stasica, M.T. Razzak and J.M. Rosiak, Radiation Physics and Chemistry. 2002, 63, 539-542.

[5] S. Shafaghi, P.N. Moghadam, A.R. Fareghi and M.M. Baradarani, Journal of Applied Polymer Science. 2014, 131, 40389.

[6] H. Rezazadeh, P.N. Moghadam, S. Ehsanimehr and A.R. Fareghi, Journal of Elastomers \& Plastics. 2020, 52, 7089. 